\title{
Character, Choice, and "Aberrant Behavior": Aligning Criminal Sentencing with Concepts of Moral Blame
}

\author{
Rachael A. Hill †
}

The United States Sentencing Guidelines aspire to create uniformity in criminal sentencing by eradicating the effects of discrimination, judicial idiosyncrasies, and biases in order to promote fairness and justice. The idea is simple: similar cases should be treated similarly. Sometimes, however, the rule-based Guidelines create the opposite result: they give similar treatment to cases with important differences. Legal norms cannot represent moral intuitions perfectly because moral intuitions necessarily vary according to facts and circumstances. Thus, situations inevitably arise where the Guidelines call for a sentence substantially more severe than our moral intuitions tell us is necessary or right.

In partial response to this problem, judges created a downward departure for "aberrant behavior" in order to address instances of diminished moral culpability. Courts use this departure to mitigate punishment for crimes representing a "single act of aberrant behavior." The circuit courts disagree, however, on how to define such an act. The majority of circuits holds that the act must be "spontaneous and thoughtless" in order to qualify. ${ }^{1} \mathrm{~A}$

$\dagger$ B.A. 1995, The University of Chicago; J.D. Candidate 1999, The University of Chicago.

${ }^{1}$ See, for example, United States $v$ Marcello, 13 F3d 752, 761 (3d Cir 1994) (holding that structured currency transactions did not constitute a spontaneous and thoughtless act); United States $v$ Glick, 946 F2d 335, 338 (4th Cir 1991) (reversing a downward departure because transport of stolen trade secrets occurred on several occasions and involved extensive planning); United States $v$ Winters, 105 F3d 200, 207 (5th Cir 1997) (holding that an officer's assault on an inmate was not spontaneous and thoughtless when he tried to cover up his actions); United States $v$ Carey, 895 F2d 318, 325 (7th Cir 1990) (holding that a check-kiting scheme was not a single act of aberrant behavior because it involved planning); United States $v$ Garlich, 951 F2d 161, 164 (8th Cir 1991) (concluding that defendant's planning and executing his financing scheme over a one year period was not "spontaneous and seemingly thoughtless"); United States $v$ Withrow, 85 F3d 527, 531 (11th Cir 1996), cert denied, $117 \mathrm{~S} \mathrm{Ct} 332$ (1996) (holding that armed theft of a car was not aberrant behavior because defendant had time to consider act); United States $v$ Dyce, 91 F3d 1462, 1470 (DC Cir 1996), cert denied, 117 S Ct 553 (1996) (noting that evidence suggests that there should be no aberrant behavior departure for a drug dealer who had ample opportunity to reconsider her decision to transport drugs). The status of the spontaneous and thoughtless test in the Eighth Circuit is somewhat uncertain in light of United 
minority of circuits has adopted a "totality of the circumstances" approach, permitting sentencing courts to take into account factors such as the defendant's pecuniary gain, prior good deeds, charitable activities, lack of criminal history or history of wrongful conduct, mitigation of the crime, mental illness, history of steady employment, and history of economic support of his or her family. ${ }^{2}$

At the most fundamental level, the circuits disagree about whether the Guidelines seek to punish an actor's choice or an actor's character. If the exercise of free will is a necessary condition for a finding of moral blame, then courts should only grant a departure to those defendants who commit spontaneous and thoughtless-and thus choiceless-acts. If character is the prope: measure of moral blame, however, courts should take a broader approach in order to determine whether a particular defendant's act expressed an underlying bad character.

This Comment argues that a character-based approach to sentencing should be adopted and implemented, in part through the downward departure for aberrant behavior. Part I describes guideline sentencing and sketches the circuits' disagreement regarding the proper definition of aberrant behavior. Part II argues that statutory language, the Guidelines Manual, and recent Supreme Court statements concerning the Guidelines provide strong implicit support for a character-based approach to sentencing. Part II also demonstrates character theory's congruence with widely accepted aims of criminal punishment. Part III positions the circuits' disagreement regarding "aberrant behavior" within the academic debate about choice versus character as the appropriate measure of moral culpability. Finally, Part IV sets forth a proposed definition of "aberrant behavior" that is consistent with a character-based approach to sentencing.

States $v$ Kalb, 105 F3d 426, 429 n 2 (8th Cir 1997) (considering and leaving open the question of whether Koon $v$ United States, 518 US 81 (1996), mandates expansion of the majority view).

${ }^{2}$ See, for example, United States $v$ Grandmaison, 77 F3d 555, 563 (1st Cir 1996) (holding that determinations of "single act of aberrant behavior" should be based on the totality of the circumstances); United States $v$ Takai, 941 F2d 738, 743 (9th Cir 1991) (same); United States v Tsosie, 14 F3d 1438, 1441-42 (10th Cir 1994) (same). Two circuits have not defined "aberrant behavior." See United States v Altman, 48 F3d 96, 104 (2d Cir 1995) (stating that the Second Circuit has "not yet confronted the issue of 'single aberrant act"); United States $v$ Duerson, 25 F3d 376, 382 (6th Cir 1994) (stating that the court is content to leave open the definition of a "single act" of aberrant behavior). 


\section{THE DOWNWARD DEPARTURE FOR ABERRANT BEHAVIOR}

\section{A. Existing Case Law}

The downward departure for aberrant behavior provides a vehicle for judicial discretion within the rule-based system of the United States Sentencing Guidelines. The Guidelines, created by the United States Sentencing Commission pursuant to the Sentencing Reform Act of $1984,{ }^{3}$ establish a uniform approach to criminal punishment. Under the Guidelines, the sentencing court identifies the level of the defendant's offense and calculates the defendant's criminal history category. ${ }^{4}$ The intersection of the offense level and the criminal history category on a sentencing grid yields the Guidelines' prescribed sentence range. ${ }^{5}$ As long as the case is "ordinary," the court must impose a sentence within this range. ${ }^{6}$ The Commission recognized, however, a "vast range of human conduct potentially relevant to a sentencing decision." Therefore, the Guidelines retain a key element of discretion: permission to depart from the Guideline range in "unusual" cases. ${ }^{8}$

Although the Guidelines themselves do not provide a comprehensive list of the types of unusual cases that might call for a departure, courts have created several distinct categories. The downward departure for aberrant behavior is one category that is employed in all federal circuits. The aberrant behavior departure originates from a passage in the Guidelines Manual in which the Commission notes that it "has not dealt with the single acts of aberrant behavior that still may justify probation at higher offense levels through departures." Although this statement refers only to probation, courts have agreed that aberrant behavior may also justify a sentence reduction. ${ }^{10}$ The circuits disagree, however, on how to define a "single act of aberrant behavior." The majority view requires that the criminal act be "spontaneous and thoughtless." This view is followed by the Third, Fourth, Fifth, Seventh, Eighth, Eleventh, and D.C. Circuits. ${ }^{11}$ A minority of cir-

3 Pub L No 98-473, 98 Stat 1988, codified at 18 USC $\S \S 3551-3673,28$ USC $\S \S 991-98$ (1994).

4 United States Sentencing Commission, Guidelines Manual \& 1B1.1 (Nov 1997) ("USSG").

Id.

- Koon v United States, 518 US 81, 92 (1996).

7 USSG Ch 1, Pt A, intro comment $4 \mathrm{~b}$.

- Koon, 518 US at 92, citing USSG Ch 1, Pt A, intro comment 4b.

- USSG Ch 1, Pt A, intro comment 4d (emphasis added).

${ }^{10}$ See United States v Duerson, 25 F3d 376, 380 (6th Cir 1994) (collecting cases).

"See note 1. 
cuits-the First, Ninth, and Tenth Circuits-has refused to adopt this approach. Instead, they examine the "totality of the circumstances," including characteristics of both the actor and his act, in deciding whether to depart. ${ }^{12}$

The majority view originated in United States $v$ Carey, ${ }^{13}$ in which the Seventh Circuit held that "[a] single act of aberrant behavior ... generally contemplates a spontaneous and thoughtless act rather than one which was the result of substantial planning. ${ }^{\prime 14}$ The majority view considers the facts of an early First Circuit case, United States $v$ Russell, ${ }^{15}$ to be paradigmatic. In Russell, the driver of an armored truck and his partner were mistakenly handed an extra $\$ 80,000$ in cash. They kept the bag of money for a week before confessing and returning it. ${ }^{16}$ According to the majority view, it is this type of behavior that may be properly classified as a single act of aberrant behavior. ${ }^{17}$ As the Seventh Circuit explained, "Russell's actions were unplanned and spontaneous; he was apparently overcome by the sudden intoxication of unexpected and immediate wealth. ${ }^{p 18}$ In the Russell case itself, the First Circuit believed that the facts warranted an "aberrant behavior" departure and remanded for clarification regarding whether the district court knew it had discretion to depart. ${ }^{19}$ Though Russell serves as the majority view's model, the First Circuit has since rejected the majority approach. ${ }^{20}$

The majority's approach to sentencing focuses exclusively on the defendant's capacity to exercise a reasoned choice to commit the criminal act. The spontaneous and thoughtless standard rests on the belief that "an act which occurs suddenly and is not the result of a continued reflective process is one for which the defendant may be arguably less accountable. ${ }^{m 1}$ The majority view also concludes that "one of the Sentencing Commission's primary

${ }^{12}$ See note 2.

${ }^{23} 895$ F2d 318 (7th Cir 1990).

14 Id at 325 (emphasis added).

${ }^{16} 870$ F2d 18 (1st Cir 1989). Though the majority uses the facts of Russell as its paradigm, the First Circuit has since rejected the majority approach. See United States $v$ Grandmaison, 77 F3d 555, 563 (1st Cir 1996) (employing a totality of the circumstances test).

${ }^{16}$ Russell, 870 F2d at 19.

${ }^{17}$ See, for example, Carey, 895 F2d at 325 (The facts of Russell present a paradigm for a single act of aberrant behavior even though the district court declined to depart in that case.).

${ }^{18}$ Id.

19870 F2d at 21.

${ }^{20}$ Grandmaison, 77 F3d at 563. Of course, the majority's enthusiasm for Russell as the paradigm case suggests that if the precise facts of the case were ever replicated, such a defendant would be entitled to a departure.

${ }^{21}$ Id at 562, quoting Carey, 895 F2d at 325. 
goals was to impose a sentence based upon the crime committed, not the offender. ${ }^{\prime 22}$ As a result, the majority approach requires something more than a showing that the act was "out of character" before it will find that the defendant exhibited aberrant behavior..$^{23}$ The majority view thus attempts to focus exclusively on the act itself and the defendant's choice to commit it. This interpretation of aberrant behavior comes close to nullifying the availability of the departure: no circuit court subscribing to the majority view has upheld a finding that a defendant's behavior was sufficiently spontaneous and thoughtless to warrant a downward departure. ${ }^{24}$

A minority of circuits-the First, Ninth, and Tenth Circuits-has rejected this constrained sentencing inquiry, electing instead to examine the "totality of the circumstances" in deciding whether to grant a departure for aberrant behavior. ${ }^{25}$ This view "place[s] considerable emphasis on a defendant's motivations and any surrounding extenuating circumstances. ${ }^{226}$ In assessing the totality of the circumstances, courts take into account factors such as the defendant's pecuniary gain, charitable activities, prior good deeds, efforts to mitigate the crime, lack of previous wrongdoing, mental illness, history of steady employment, history of economic support for his or her family, and other psychological and motivating factors. ${ }^{27}$ In essence, the minority view holds that a departure is warranted when the defendant's behavior can be described as "a complete shock and out of character. ${ }^{228}$ Courts adopting the minority view usually define "out of character" relative to the defendant's previous conduct; some, however, define it relative to the behavior of other offenders committing the same offense. ${ }^{29}$ Under either definition, the mi-

${ }^{22}$ United States $v$ Brewer, 899 F2d 503, 507 (6th Cir 1990), citing United States v Mejia-Orosco, 867 F2d 216, 218 (5th Cir 1989).

${ }^{2}$ United States $v$ Williams, 974 F2d 25, 26 (5th Cir 1992).

${ }^{24}$ See note 1.

${ }^{25}$ See note 2. Although the Ninth Circuit initially led the totality of the circumstances pack, the court has shifted toward a spontaneous and thoughtless approach. See United States $v$ Pierson, 121 F3d 560, 564-65 (9th Cir 1997) (applying Carey and declining to depart); United States $v$ Green, 105 F3d 1321, 1323 (9th Cir 1997) ("While we have not required that the behavior be a single spontaneous or thoughtless act involving no planning, we have to some extent relied on the concept of 'singularity or spontaneity." ), citing United States $v$ Lam, 20 F3d 999, 1004 (9th Cir 1994).

${ }^{25}$ Green, 105 F3d at 1323.

${ }^{27}$ Grandmaison, 77 F3d at 563 (listing factors); United States v Lam, 20 F3d 999, 1003-05 (9th Cir 1994) (same); United States v Fairless, 975 F2d 664, 667-68 (9th Cir 1992) (same); United States v Tsosie, 14 F3d 1438, 1441-42 (10th Cir 1994) (same).

23 Tsosie, 14 F3d at 1441.

${ }^{2}$ Compare Tsosie, 14 F3d at 1441 ("The totality of circumstances must be viewed to see whether the offense fits within [the defendant's] normal conduct or if it is a complete 
nority view involves a wider scope of inquiry in the downward departure decision because it permits courts to consider aspects of the actor's character and previous history as well as his act.

\section{B. The Connection Between the Aberrant Behavior Split and Competing Notions of Moral Blame}

At first glance, the proper definition of aberrant behavior might seem to be a minor and peripheral issue-a simple debate about the appropriate legal standard to be applied in a relatively small number of cases. Upon further examination, however, the problem emerges as a more complex and fundamental issue. The Sentencing Commission's decision to couple the rule-based Guidelines with judicial discretion to depart indicates that the Guidelines seek to accomplish something more than to punish the criminal act itself. After all, if mere conduct is a complete indicator of blameworthiness, then a simple sentencing grid produces perfect results. What, then, is this "something more"? The two distinct approaches to the aberrant behavior issue suggest two possible answers: either the Guidelines seek to punish choice, or they seek to punish character.

The majority view assesses spontaneity and thoughtlessness, apparently gauging the actor's capacity to exercise reasoned choice. In the majority's view the Guidelines are motivated by the belief that actors are criminally responsible for the acts they freely choose to undertake but not for acts they lack either the capacity or the opportunity to avoid doing..$^{30}$ In contrast, the minority's consideration of psychological and motivating factors indicates an assumption that the Guidelines intend to punish something about the actor himself-namely, his character. These courts apparently believe that actors are criminally responsible only for those actions that express a morally reprehensible character trait. ${ }^{31}$ Within the character-based approach there is yet an-

shock and out of character."), with United States $v$ Delvalle, 967 F Supp 781, 784 (E D NY 1997) (granting a departure under a totality of the circumstances approach after finding the defendant's conduct aberrant both in comparison to other offenders and to his own previous conduct). See also United States $v$ Takai, 941 F2d 738, 744 (9th Cir 1991) (holding that the defendants' behavior in attempting to bribe an INS official was aberrant in comparison to the "usual undercover case").

${ }^{\text {so }}$ For discussions of choice-based approaches to culpability, see R.A. Duff, Choice, Character, and Criminal Liability, 12 L \& Phil 345, 346-47 (1993); Michael S. Moore, Choice, Character, and Excuse, 7:2 Soc Phil \& Pol 29, 29 (1990).

${ }^{31}$ For discussions of character-based approaches to culpability, see Duff, 12 L \& Phil at 362-63; Peter Arenella, Character, Choice, and Moral Agency: The Relevance of Character to our Moral Culpability Judgments, 7:2 Soc Phil \& Pol 59, 81 (1990); Michael D. Bayles, Character, Purpose, and Criminal Responsibility, 1 L \& Phil 5, 7 (1982). 
other possible division. Most courts applying the minority approach seem to believe character can be measured by "settled dispositions," components of an actor's character that exist independently of the criminal act. ${ }^{32}$ These might include prior good deeds and support for family. However, another more limited conception of character is possible-one that looks only to the emotions and motivations behind the criminal act itself.

If the majority is correct that the Guidelines seek to punish choice, then spontaneous and thoughtless is a sensible definition for aberrant behavior, because it focuses the judicial inquiry directly on the actor's capacity for rational choice. If, however, the Guidelines intend to punish the actor's character, the inquiry must go beyond spontaneous and thoughtless in order to reach a wider range of the actor's personal characteristics and motivations. This character-based approach might resemble the totality of the circumstances approach of the minority. Reaching consensus on the proper definition of aberrant behavior, then, requires an understanding of the Guidelines' basic conception of moral blame-namely, whether the Guidelines seek to punish an actor's choice or the actor himself.

Statutory language, the Guidelines Manual, and Supreme Court statements concerning the nature of the Guidelines do not explicitly endorse either choice or character as the proper measure of moral culpability. They do, however, provide strong implicit support for a character-based approach. Furthermore, using character as the touchstone of moral fault accords squarely with the commonly accepted aims of criminal punishment, now codified by Congress for use as the proper purpose of the Guidelines.

\section{SUPPORT FOR A CHARACTER-BASED APPROACH TO SENTENCING}

Language in the Sentencing Reform Act of 1984, the Guidelines Manual, and recent Supreme Court jurisprudence supports a character-based approach to criminal sentencing. The theoretical underpinnings of criminal punishment also favor a characterbased approach. Although neither Congress, the Sentencing Commission, nor the Supreme Court explicitly endorses any measure of moral fault, ${ }^{33}$ a character-based approach appears to be most congruent with the current sentencing regime.

${ }^{32}$ See notes 27-29 and accompanying text.

${ }^{3}$ See Kevin Cole, The Empty Idea of Sentencing Disparity, 91 Nw U L Rev 1336, 1336 (1997) ("For all the sophistication they display, the Federal Sentencing Guidelines also reflect a defiant atheoreticality."). 


\section{A. Statutory Language, the Guidelines Manual, and Koon}

Congress, the Sentencing Commission, and the Supreme Court each have provided considerable support for a characterbased approach to sentencing. ${ }^{34}$ In the act that established the Sentencing Commission, Congress directed federal district courts to focus on "the nature and circumstances of the offense and the history and characteristics of the defendant. ${ }^{335}$ The Commission itself has stated that, when considering a departure from a Guidelines-prescribed sentence, "the court may consider, without limitation, any information concerning the background, character and conduct of the defendant. ${ }^{\text {"36 }}$ The Commission has also explained that its decision to permit discretionary upward and downward departures stemmed from a recognition that "it is difficult to prescribe a single set of guidelines that encompasses the vast range of human conduct potentially relevant to a sentencing decision. ${ }^{n 37}$ These official pronouncements deliberately eschew a strictly act-based inquiry at the sentencing phase, favoring instead a broader approach that includes considerations of character.

During the first decade of the Guidelines' use, however, some courts expressed what Professor Albert Alschuler has called "a common misperception" about the Sentencing Guidelines, ${ }^{38}$ namely, that '[o]ne of Congress' primary purposes in establishing the Guidelines was ... to rest sentences upon the offense committed, not upon the offender. ${ }^{339}$ This perception has been used to justify the majority approach to the aberrant behavior departure. ${ }^{40}$ Yet Congress specifically charged the Commission with creating a system of punishment that would consider both the act and the offender. Therefore, if the Guidelines require courts to consider only the offense, then "a serious question would arise

${ }^{34}$ See also Dan M. Kahan and Martha C. Nussbaum, Two Conceptions of Emotion in Criminal Law, 96 Colum L Rev 269, 369 (1996) (pointing to "a long moral and legal tradition" that holds "that we owe it to the dignity and humanity of the defendant to let the entire history appear").

${ }^{35} 18$ USC $\$ 3553(a)(1)$.

${ }^{38}$ USSG \& $1 B 1.4$.

${ }^{37}$ USSG Ch 1, Pt A, intro comment $4 \mathrm{~b}$.

${ }^{38}$ Albert W. Alschuler, The Failure of Sentencing Guidelines: A Plea for Less Aggregation, 58 U Chi L Rev 901, 910 (1991).

${ }^{3}$ Id, quoting United States v McHan, 920 F2d 244, 247 (4th Cir 1990). See also United States v Brewer, 899 F2d 503, 507 (6th Cir 1990) (Guidelines require courts to focus on offense.); United States v Mejia-Orosco, 867 F2d 216, 218 (5th Cir 1989) (The punishment should fit the crime, not the offender.).

${ }^{40}$ See note 22 and accompanying text. 
whether the Guidelines must be struck down for failure to conform to the governing statute. ${ }^{.41}$

The Supreme Court's 1996 decision in Koon v United States ${ }^{42}$ confirmed that the "act only" understanding of the Guidelines was indeed a serious misperception. In a portion of the Koon opinion that was joined by all nine Justices, the Court clarified the correct focus of the sentencing inquiry:

[T]he Guidelines provide uniformity, predictability, and a degree of detachment lacking in our earlier system. This too must be remembered, however. It has been uniform and constant in the federal judicial tradition for the sentencing judge to consider every convicted person as an individual and every case as a unique study in the human failings that sometimes mitigate, sometimes magnify, the crime and the punishment to ensue. ${ }^{43}$

Koon deflects the assumption that the Guidelines are wholly actbased-an assumption the majority of courts use to substantiate adherence to spontaneous and thoughtless as the proper definition of aberrant behavior.

Furthermore, in Koon the Court directed the district court to "make a refined assessment of the many facts bearing on the outcome, informed by its vantage point and day-to-day experience in criminal sentencing. ${ }^{344}$ Only a character-based approach, which takes account of emotional motivation, can encompass such breadth of analysis. The choice-based approach limits the sentencing judge to deciding whether the defendant lacked the capacity or opportunity for rational choice. In contrast, the character-based approach permits the sentencing judge to fully examine "the human failings that sometimes mitigate, sometimes magnify, the crime and the punishment to ensue. ${ }^{345}$ Therefore, Koon seems incompatible with a choice-based understanding of Guidelines sentencing on two fronts. ${ }^{46}$

"United States v Rodriguez, 724 F Supp 1118, 1120 (S D NY 1989).

42518 US 81 (1996).

${ }^{43}$ Id at 113 (emphasis added).

4 Id at 98.

${ }^{45}$ Id at 113.

${ }^{48}$ Moreover, the Eighth Circuit has suggested a third conflict between Koon and the "spontaneous and thoughtless" standard. See United States v Kalb, 105 F3d 426 (8th Cir 1997). Koon requires a two-step inquiry before departure: first, whether the given factor is encouraged or merely "unmentioned," and second, if the factor is unmentioned, whether the facts of the case take it outside the "heartland" of ordinary cases. Koon, 518 US at 96. According to the Eighth Circuit, assessing only spontaneity and thoughtlessness might be an impermissibly narrow "heartland" inquiry. See Kalb, 105 F3d at 429 \& $n 2$. 


\section{B. Character and the Aims of Punishment}

Using character as the measure of moral blame also comports closely with long-accepted rationales for the imposition of criminal punishment. Commentators typically identify the four major aims of punishment as retribution, deterrence, incapacitation, and rehabilitation. ${ }^{47}$ When Congress created the United States Sentencing Commission and charged the Commission with creating the Sentencing Guidelines, it codified these same rationales as the proper factors to be considered by the sentencing judge. Specifically, Congress stated:

The court, in determining the particular sentence to be imposed, shall consider . . . the need for the sentence imposed(A) to reflect the seriousness of the offense, to promote respect for the law, and to provide just punishment for the offense; (B) to afford adequate deterrence to criminal conduct; (C) to protect the public from further crimes of the defendant; and (D) to provide the defendant with needed educational or vocational training, medical care, or other correctional treatment in the most effective manner. ${ }^{48}$

A character-based approach to sentencing ensures that treatment of the individual offender satisfies all four major aims of punishment. A choice-based approach, however, fails to meet all four goals consistently.

\section{Retribution.}

Retribution requires that punishment be just, reflecting the actor's desert and the seriousness of his offense. A character inquiry enables judges to make more accurate determinations about desert. Under a character-based approach to sentencing, even if two actors have performed identical acts, the character of one actor may make him more deserving of punishment than the other. Though at least one choice theorist argues that it is inappropriate to punish two actors differently for similar acts, ${ }^{49}$ basic moral intuitions suggest otherwise. Consider two actors, A and B, both of whom have killed another human being. A made an ago-

${ }^{47}$ See, for example, Sanford H. Kadish and Stephen J. Schulhofer, Criminal Law and its Processes: Cases and Materials 101-31 (Little, Brown 6th ed 1995); Kent Greenawalt, Punishment, in Sanford H. Kadish, ed, 4 Encyclopedia of Crime and Justice 1336-45 (MacMillan 1983).

18 USC \& 3553(a).

49 See Benjamin B. Sendor, The Relevance of Conduct and Character to Guilt and Punishment, 10 Notre Dame J L Ethics \& Pub Pol 99, 129-30 (1996) (arguing that "in criminal law, desert entails a judgment based upon conduct . . . not a judgment about character"). 
nizing choice to shoot his own father, who was suffering from a terminal illness and wished to die. B, on the other hand, shot an African-American neighbor out of racial hatred. Whatever one's view about the morality of euthanasia, society's impulse is to punish those who kill out of mercy less than those who kill out of hate. This impulse is reflected in the doctrines of excuse and justification, which prescribe diminished punishment in cases of diminished moral culpability. For example, the criminal law punishes those who are motivated to act out of necessity or under duress less severely than those who are not. Retributive urges are variable, based on both the core conduct involved in committing the offense and the emotions and motivations driving the act. Therefore, a character-based approach to sentencing serves the goal of retribution better than a choice-based approach.

\section{Deterrence.}

At first glance, deterrence may seem to be a trickier fit for the character theorist, because pure deterrence thinking is closely tied to choice theory. Nevertheless, a character-based approach to sentencing will provide adequate amounts of both specific and general deterrence. More importantly, it will deter the "right" people.

Focusing the sentencing inquiry on character satisfies the demands of specific deterrence. Commentators agree that the criminal law regime attempts to replicate closely society's notions of moral blame. ${ }^{50}$ Thus, the criminal law should, and usually does, operate to punish only the morally "bad." Conversely, because legal norms reflect moral norms, people with morally "good" characters only rarely do things that are legally "bad." Such cases occur only in the gap between moral and legal norms; if the criminal law operates properly, this gap ought to be very narrow. Consequently, if the overwhelming majority of "bad" acts are committed by "bad" people, the chance that a morally "good" person will repeat his legally "bad" behavior is lower than the chance that a

${ }^{60}$ See, for example, Moore, 7:2 Soc Phil \& Pol at 30 (cited in note 30) (observing a very tight connection between morality and legality in the criminal law); Arenella, 7:2 Soc Phil $\& \mathrm{Pol}$ at 61 (cited in note 31) ("One of the major distinctions between the criminal law and other legal methods of constraining people's behavior is that a criminal conviction often conveys a message of moral as well as legal censure."); Sanford H. Kadish, Blame and Punishment: Essays in the Criminal Law 87 (MacMillan 1987) ("[C]riminal conviction charges a moral fault."); George Vuoso, Note, Background, Responsibility, and Excuse, 96 Yale L J 1661, 1663 (1987) ("Only a criminal law that incorporated to some extent the morality of the society it was supposed to serve, could hope to endure and effectively achieve general deterrence and the other societal benefits that are thought to justify criminal punishment."). 
"bad" person will. By punishing only those people motivated by their "bad" characters, courts can ensure that criminal sentences specifically deter precisely those people who most need to be deterred from future criminal conduct.

The aim of general deterrence-using the defendant to set an example in order to dissuade misconduct by others-is also tied to a choice-based approach to sentencing. Future actors can only alter their chosen behavior; therefore, punishing an actor for choosing to behave badly encourages others to choose to behave well. However, this link between general deterrence and choice theory does not exclude the possibility that a character-based approach might have similar deterrent effects. In fact, if actors can evaluate the quality of their own motivations, optimal general deterrence ought to be achieved under a character-based approach. A "bad" person will be deterred by the punishment given to other "bad" actors. Proponents of choice as the proper measure of moral fault might argue that people are not good at self-identification, and that optimal deterrence will not obtain whenever "bad" people misidentify their own motivations as "good." While it is true that actors may be deluded as to the intrinsic moral quality of their own actions, the proper measuring stick for the future actor is society's valuation of the given motivation, not the actor's valuation. An actor planning to commit a hate crime, for example, will observe the differentiation between the punishment given to actors $A$ and $B$ in the earlier example. Even though this third actor, $\mathrm{C}$, might believe that killing a member of another race is as morally justified as killing one's father out of mercy, $\mathbf{C}$ will recognize that society labels the former action as more morally reprehensible than the latter. $C$ will self-identify with $B$, and A's reduced punishment ought not diminish the resultant deterrent effect.

Furthermore, even if a self-identification problem does exist, the decrease in general deterrence is likely to be quite slim. The "good" people with whom the "bad" actor wrongly self-identifies do not avoid punishment entirely; they are just punished less. Judge Posner has pointed out that marginal differences in deterrence arising from criminal sentences can be very small. ${ }^{51}$ This slight slippage in general deterrence is more than justified by the efficiency gains in specific deterrence and the clear superiority of the character-based approach over choice as a means of fulfilling the other major aims of punishment.

${ }^{31}$ See United States $v$ Jackson, 835 F2d 1195, 1199-1200 (7th Cir 1987) (Posner concurring). 
3. Social Protection and Rehabilitation.

A character-based approach to sentencing also provides the appropriate level of social protection. Again, the parallel between moral and legal norms means that "good" people are less likely than "bad" people to commit dangerous or undesirable acts in the future. ${ }^{52} \mathrm{~A}$ choice-based approach, on the other hand, is more likely to punish "good" people too severely by treating them the same as the "bad" people who pose a more serious danger to the public. Similarly, character theory furthers the rehabilitative aim of punishment because "good" people are "good" and do not need to become "good" through "educational or vocational training, medical care, or other correctional treatment. ${ }^{.53}$ Using character at the sentencing phase ensures that society expends its resources primarily on those from whom it most wants to be protected and who need the most rehabilitative help. A choice-based approach cannot make such distinctions.

In short, character theory's congruence with the aims of punishment, along with statements from Congress, the Sentencing Commission, and the Supreme Court, strongly support a character-based approach to criminal sentencing. Because neither Congress nor the Supreme Court has explicitly approved this approach, however, it is helpful to consider the contributions of criminal law theorists. The next Part analyzes the ongoing choice-character debate and endorses character theory as a superior measure of moral fault.

\section{The ACADEMic Debate: Choice Versus Character}

Because Congress, the Sentencing Commission, and the Supreme Court have failed to resolve conclusively the choicecharacter question, the issue remains open for academic discussion. Indeed, there exists a lively and ongoing debate regarding which of the two competing notions of moral culpability ought to govern understandings of the entire body of criminal law. ${ }^{54}$

${ }^{52}$ See Sendor, 10 Notre Dame J L, Ethics \& Pub Pol at 128 (cited in note 49) ("An offender's bad or good character plainly is an appropriate sentencing criterion for the purpose of incapacitating an offender.").

${ }^{33} 18$ USC § 3553(a)(2)(D). See also Sendor, 10 Notre Dame J L Ethics \& Pub Pol at 129 (cited in note 49) ("The rehabilitative function of punishment clearly requires the use of a defendant's character as a criterion of punishment.").

st The debate between these two competing conceptions has been waged on both positive and normative grounds. Lately, character and choice theorists have focused on describing and explaining legal excuses and justifications such as insanity, duress, and mistake. While character and choice theorists agree that the criminal law does and should use these doctrines to recognize diminished culpability in certain circumstances, they disagree about whether it is the lack of free choice or the absence of bad character that best ex- 


\section{A. Choice Theory}

Choice theory derives from Kant's belief in the will as the source of human morality. ${ }^{55}$ Blackstone applied this concept to the criminal law, arguing that legal excuses can be "reduced to this single consideration, the want or defect of will." "The theory's first major modern proponent was H.L.A. Hart, who wrote that excuses "reflect, albeit imperfectly, a fundamental principle of morality that a person is not to be blamed for what he has done if he could not help doing it. ${ }^{357}$ According to Hart, assigning moral blame to an actor is fair and just only when the actor has both the capacity and the fair opportunity to conform to the law. ${ }^{58}$ As long as the actor's behavior is chosen freely, however, the actor is morally responsible for his acts.

Choice theory has strong connections to deterrence. ${ }^{59}$ If actors know that they will be legally responsible for deliberately breaching moral norms, they will choose not to breach them in order to avoid punishment. ${ }^{60}$ Choice theorists, however, also ground the theory in basic fairness ideals that function as moral side-constraints on the purely utilitarian goal of minimizing crime in any cost-effective manner. ${ }^{61}$ In Harts words, these are constraints that "civilized moral thought place[s] on the pursuit of the utilitarian goal by the demand that punishment should not be applied to the innocent. ${ }^{362}$ In this context, the innocent are those actors who could not have chosen otherwise. "Could not," however, is loosely defined: an actor's choice to obey the legal

plains and justifies the concept of reduced culpability. This dispute parallels the debate over the correct definition of aberrant behavior. It therefore applies with equal force to the sentencing phase of criminal adjudication.

${ }^{65}$ See Duff, 12 L \& Phil at 346 (cited in note 30); Bayles, 1 L \& Phil at 6 (cited in note 31).

${ }^{58}$ Moore, 7:2 Soc Phil \& Pol at 32 (cited in note 30), quoting Sir William Blackstone, 4 Commentaries on the Laws of England 20 (Chitty ed 1826).

${ }^{67}$ H.L.A. Hart, Punishment and Responsibility 174 (Oxford 1968).

${ }^{s 8}$ Id at 201.

${ }^{\circ}$ See text accompanying notes $47-48$.

${ }^{6}$ See Moore, 7:2 Soc Phil \& Pol at 33 (cited in note 30) (" $[0]$ lnly my free choices will be sanctioned, and knowing that, I can maximally predict what will follow upon my decisions."); Duff, $12 \mathrm{~L} \&$ Phil at 347 (cited in note 30) (citing Hart for the point that a choicebased approach to the measurement of moral blame results in rational choice maximization).

${ }^{61}$ Moore, 7:2 Soc Phil \& Pol at 33 (cited in note 30) (citing Hart for the proposition that the choice principle originates from considerations of fairness and justice); Duff, $12 \mathrm{~L} \&$ Phil at 347 (cited in note 30 ) ("Only [my choices] are properly mine as a responsible agent, since only they are within my control."). See also Arenella, 7:2 Soc Phil \& Pol at 62 (cited in note 31 ) ("[U]tilitarian theorists . . treat[ ] the moral responsibility requirement as a useful side-constraint on the law's goal of crime-prevention.").

${ }^{62}$ Hart, Punishment and Responsibility at 80 (cited in note 57). 
norm need not have been completely impossible, but merely very difficult. ${ }^{63}$ This difficulty can be either intrinsic or extrinsic to the actor. Lack of capacity to choose includes intrinsic factors such as insanity, and lack of fair opportunity may describe external circumstances. $^{64}$ In either case, the actor's excuse or justification stems exclusively from an inability to exercise unfettered choice.

\section{B. Character Theory}

The character theory of criminal responsibility derives, at least in part, from the work of David Hume, who located "personal character" as the situs of moral blame. ${ }^{65}$ According to character theory, criminal actions serve as a lens through which to view an actor's character traits. If a particular action expresses bad character, the actor is morally blameworthy. However, the occasional gap between legal and moral norms may lead to a false inference from act to character. In such cases, the actor cannot be shown to have a bad character and, therefore, deserves less (or no) moral blame. ${ }^{66}$ For example, a law against killing covers, on its face, both sadistic serial murderers and those who kill in selfdefense, even though society considers actors in the latter category to be less morally culpable. In cases such as this, where no connection exists between act and bad character, the lack of mens rea, or the presence of an excuse or justification, blocks the inference linking the criminal act to bad character. Character theory seeks to identify these gaps between legal and moral norms in order to perfect character inferences and mete out moral blame accordingly.

Some character theorists take a broad, "settled dispositions" approach to character, arguing that moral blame attaches according to the actor's established character traits as evidenced by a pattern of action over time. ${ }^{67}$ Most, however, are careful to re-

a Moore, 7:2 Soc Phil \& Pol at 34-35 (cited in note 30) (arguing for a compatible reading of "could not have done otherwise" that embraces situations where choice is very difficult).

ot See id at 35 (describing Hart's bifurcation of capacity and opportunity as a distinction between the actor's "equipment" and the actor's situation).

${ }^{\star 6}$ See Duff, 12 L \& Phil at 361 \& n 49 (cited in note 30); Bayles, 1 L \& Phil at 7 (cited in note 31).

${ }^{66}$ See Duff, 12 L \& Phil at 363 (cited in note 30) ("[A defendant] is convicted if and because his action warranted an inference to an undesirable character-trait; it is that character-trait which the law condemns and punishes."); Bayles, $1 \mathrm{~L} \&$ Phil at 7 (cited in note 31) ("If an act does indicate an undesirable character trait, then blame is appropriate; if it does not, then blame is inappropriate.").

" See, for example, Bayles, $1 \mathrm{~L} \&$ Phil at 7 (cited in note 31) ("[Character trait] refers to any socially desirable or undesirable disposition of a person."); Nicola Lacey, State Punishment: Political Principles and Community Values 68 (Routledge 1988) ("[I]t is unfair to 
ject this behavioral approach ${ }^{68}$ in favor of a narrower, motivational inquiry. ${ }^{69}$ The settled dispositions approach fails because it generates an account of criminal responsibility that is at once "too rich" ${ }^{\text {s70 }}$ and inherently unreliable. The criminal law is illequipped to undertake a complex psychological analysis of moral qualities and tendencies expressed over the course of an actor's entire life. Moreover, such evidence ought to have little bearing on intuitions regarding the appropriate amount of moral blame attaching to a particular criminal act. As Professor R.A. Duff explains:

What makes a person's action 'out of character' in the relevant sense is not its inconsistency with what he has shown in other contexts to be his settled dispositions, but that it does not manifest 'character' at all: it does not, that is, manifest the kind of valuational and motivational structure of attitudes and practical reasoning in which a person's 'character,' as an object of moral or criminal appraisal, consists. ${ }^{71}$

For example, in forming intuitions about blame in the hypothetical involving $A$ and $B$, it is A's merciful motives and B's racist ones that matter most. Evidence of A's history of convenience store robbery or B's involvement with various charities should hold no sway, even if they tell us something about "character" in a broader sense. When "motivational" character theorists assess character, they look to the emotions and motivations underlying the criminal act itself, because only a motivational analysis provides an accurate measurement of moral blame.

\section{Character Theory as a More Complete Account of Moral Blame}

Character theory is superior to choice theory because it recognizes that some human emotions and motivations are not chosen, and yet are still morally blameworthy. According to character theorists, choice theory is not completely wrong; rather, it is

hold people responsible for actions which are out of character, but only fair to hold them so for actions in which their settled dispositions are centrally expressed.").

${ }^{63}$ See Arenella, 7:2 Soc Phil \& Pol at 78-79 (cited in note 31) (describing as "outmoded" the behavioral view of character as a description of a person's past acts or settled dispositions); Duff, 12 L \& Phil at 368 (cited in note 30) ("[T]he criminal process is radically illsuited to serve as an inquiry into the subtler depths of a defendant's moral character; nor is an inquiry the law's proper business.").

* See Arenella, 7:2 Soc Phil \& Pol at 79 (cited in note 31) (endorsing a motivational view of character); Duff, $12 \mathrm{~L} \&$ Phil at 378 (cited in note 30 ) (same).

${ }^{70}$ Duff, $12 \mathrm{~L} \&$ Phil at 368 (cited in note 30 ).

"Id at 378 (emphasis added). 
"thin" or "inadequate." Choice theory's narrow focus on volition and reason fails sufficiently to take account of other human processes. ${ }^{73}$ While character theorists define themselves in opposition to choice theorists, they also recognize an "intimate link" between character and choice. ${ }^{74}$ Character is evidenced most clearly by the types of choices an actor makes. ${ }^{75}$ Professor Peter Arenella augments choice-based analysis by examining the source and content of the actor's goals, desires, values, and emotions as well as their bearing on moral agency. ${ }^{76}$ As Duff explains, this type of inquiry sets the action "in the wider and deeper context of thought, attitudes, and motivation that gives it its meaning. ${ }^{m 7}$

Choice theorists, however, recognize that a concept of moral responsibility that ignores most human emotions and motivations is inherently inadequate. They have attempted to remedy this problem without conceding the superiority of the character-based approach. In response to the problem that some forces that constrain choice do not justify committing crimes, Professor Michael Moore, a choice theorist, posits that some emotions are part of the actor himself. These emotions cannot be seen as external forces that constrain, and therefore excuse, an actor's choice to commit a crime. Moore gives the example of an individual, $\mathrm{D}_{2} . \mathrm{D}_{2}$ unjustifiably hates another individual, $X$, who is, by all accounts, a wonderful person. $X$ is dying but can be saved by a rare drug possessed by $T$. $T$ knows of $\mathrm{D}_{2}$ 's hatred for $\mathrm{X}$ and tries to force $\mathrm{D}_{2}$ to rob a bank by threatening to give $X$ the drug. $D_{2}$ does not want to rob the bank but is overcome by the thought of X's continued existence. He therefore agrees to help $\mathrm{T}^{78}$ Under a simple choicebased approach, $D_{2}$ may qualify for a duress excuse. He fears X's continued existence just as another actor might fear harm to his family. This fear incapacitates his ability to choose; therefore, he is not culpable. According to Moore, however, this answer is be-

72 See Arenella, 7:2 Soc Phil \& Pol at 64 (cited in note 31) ("thin"); Duff, 12 L \& Phil at 361-62 (cited in note 30) ("inadequate").

${ }^{73}$ See Arenella, 7:2 Soc Phil \& Pol at 64 (cited in note 31); Duff, 12 L \& Phil at 361-62 (cited in note 30).

"See Arenella, 7:2 Soc Phil \& Pol at 61 (cited in note 31). See also Duff, 12 L \& Phil at 380 (cited in note 30 ) ("What makes a person criminally liable is . . . not 'choice' as distinct from 'character'; nor 'character' as distinct from 'choice' or action: but a wrongful action which, as the action of a responsible moral agent, manifests in and by itself some inappropriate attitude towards the law and the values it protects."). See also note 66.

${ }^{75}$ See Arenella, 7:2 Soc Phil \& Pol at 74 (cited in note 31); Duff, 12 L \& Phil at 371-72 (cited in note 30 ).

${ }^{76}$ See Arenella, 7:2 Soc Phil \& Pol at 61 (cited in note 31).

7 Duff, $12 \mathrm{~L} \&$ Phil at 372 (cited in note 30 ).

${ }^{73}$ Moore, 7:2 Soc Phil \& Pol at 36-37 (cited in note 30). 
lied by "[c]ommon intuition."79 This intuition "should incline the choice theorist strongly toward Freud's view: some emotions, at least, have to be included within the self who chooses. $D_{2}$ 's hatred of $X$ is part of him; it cannot be seen as an alien factor that incapacitates him from deciding whether or not to rob the bank. ${ }^{.180}$

Anticipating the character theorists' response, Moore says that "[s]uch an extended view of self may seem unavailable on the choice theory of responsibility, for it may seem that to hold people like $\mathrm{D}_{2}$ responsible for their actions requires a prior judgement holding them responsible for being who they are. ${ }^{781}$ Moore answers in a conclusory fashion. Without explaining how an extended view of self can be reconciled with choice theory, Moore simply states that it can: "Choice, to be morally interesting, must include not only the initiation of basic actions but also the formation of the intentions and beliefs that guide and motivate the doing of basic actions. ${ }^{\$ 22}$ But when Moore tries to bring emotions and human motivations within the purview of choice theory, the result is not choice theory at all ${ }^{83}$ Instead, Moore is left with precisely the kind of character-based approach he set out to discredit.

Not surprisingly, Moore encounters difficulty when he applies what he maintains is choice theory to the case of $D_{2}$ in a way that distinguishes the analysis from one overtly based on character. Deciding to leave the issue open, Moore refuses to grapple with the question of whether emotions such as $\mathrm{D}_{2}$ 's hatred can be said to incapacitate choice. ${ }^{84}$ Instead, Moore focuses his attention on the "lack of fair opportunity" strand of choice theory, arguing that $D_{2}$ does not lack fair opportunity to conform to the legal norm because he does not face an "objectively regarded" evil if he does conform. ${ }^{85}$ In other words, $D_{2}$ is not excused for committing a crime in order to prevent X's survival, because X's survival is not an evil to society but rather a benefit (especially because $\mathrm{X}$ is a wonderful person). Moore does not, however, explain how to determine whether an outcome is objectively evil. How do we know X's survival is a good thing? More importantly, how do we know $\mathrm{D}_{2}$ is morally wrong to hate $\mathrm{X}$ ? Measuring objective evilness presupposes an inquiry into $D_{2}$ 's character. Arenella makes this

\footnotetext{
79 Id at 37.

${ }^{80}$ Id at 37-38.

si Id at 38.

82 Id.

See Arenella, 7:2 Soc Phil \& Pol at 80 (cited in note 31).

st Moore, 7:2 Soc Phil \& Pol at 39-40 (cited in note 30).

ss Id at 40.
} 
point when he notes that Moore's criterion of objective evil does nothing more than serve as a "proxy for evaluating whether the individual's succumbing to the threat reflected a morally objectionable character trait for which we hold the agent morally responsible. ${ }^{\text {"86 }}$

Arenella also points out that even the basic form of choice theory contains a certain disguised acceptance of the characterbased approach. For example, imagine an extremely irascible person, E. E is walking down the street when another person, F, accidentally bumps his shoulder as they pass. True to his nature, $\mathrm{E}$ becomes inflamed. Without thinking, he pulls out a gun and shoots $\mathrm{F}$ to death. Under a strict application of choice theory, $\mathrm{E}$ ought to be excused, because his excessive anger made the choice not to kill $F$ very difficult. This is a perverse result ${ }^{87}$ that the law anticipates and avoids. In order to qualify for excuses such as provocation and duress, an actor must behave as a reasonable person or a person of reasonable firmness. Choice theory, however, "does not explain how . . . the choice theorist's minimalist account of a moral agent's necessary attributes can generate this capacity" to behave reasonably. ${ }^{88}$ Using a hypothetical reasonable person as a baseline introduces a concealed character judgment into the choice-based approach. As with Moore's "objectively regarded as evil" test, a reasonable person standard requires courts to assess whether an actor's reaction to a perceived threat or affront reveals a character trait that is undesirable according to society's standards. When an actor behaves unreasonably, he expresses a bad character and is, therefore, morally blameworthy. When an actor acts as a reasonable person would, he does not reveal a bad character and is excused. These examples show that whenever choice theorists attempt to. give their theory more explanatory power, they lapse into a character-based inquiry.

\section{DEFINING ABERRANT BeHAVIOR TO REFleCT A CHARACTER-} BASED APPROACH TO SENTENCING

Commentators have focused on defending character theory as an explanation and justification for the concept of criminal re-

* Arenella, 7:2 Soc Phil \& Pol at 78 (cited in note 31).

"See Kahan and Nussbaum, 96 Colum $L$ Rev at 307-08 (cited in note 34) ("A rule that focused only on impairment of volition would thus risk getting things entirely backwards; it would show more solicitude toward the 'proud, or captious, or selfish or habitually illnatured man'- who by any sort of indulgence, fault, or vice, renders himself very easily excitable, or very subject to temptation'-than it would toward the 'moderate, welltempered, and orderly citizen." (citations omitted).

* Arenella, 7:2 Soc Phil \& Pol at 70-71 (cited in note 31). 
sponsibility. Because both criminal responsibility and the appropriateness of punishment depend on a finding of blame, character theory is also the most complete and coherent approach to criminal punishment. Character theory's superiority is borne out by the implicit support for a character-based approach to sentencing in the Sentencing Guidelines, and in legislative and Supreme Court statements about the Guidelines. To implement a character-based approach fully, however, courts must base their definition of aberrant behavior on a motivational understanding of character theory. Currently, neither the majority's spontaneous and thoughtless test nor the minority's totality of the circumstances approach represents a truly character-based sentencing inquiry.

\section{A. Rejecting the Choice-Based Majority View}

The majority view regarding the proper definition of aberrant behavior constitutes an attempt to apply choice theory to criminal sentencing. Like choice theory generally, however, this choicebased approach to sentencing is an inherently inadequate and misleading account of moral culpability. Moral intuitions about blame and punishment depend on much more than a simple assessment of choice. In fact, a finding of spontaneity and thoughtlessness may be more consistent with increased, rather than decreased, moral blame. On this score, Duff argues that:

It would be absurd to argue that we should not be morally or criminally liable for our weak-willed actions; and such actions surely reflect relevant character-traits. They show something about the nature and depth of our commitment to the values they flout; they show that we lack the moral strength to resist temptations that a more virtuous person would resist—or would not even be tempted by. ${ }^{89}$

Take, for example, the Russell defendant. The majority of circuits considered his behavior to be spontaneous and thoughtless, and the First Circuit considered it possibly aberrant within the meaning of the departure..$^{90}$ Russell made a split-second decision to keep $\$ 80,000$ that did not belong to him; he returned the money a week later. While Russell might not be a hardened criminal, it is not clear that we must blame him less for the immediacy of his decision to steal. Isn't it possible that his heedless action actually revealed a greater moral culpability? Would we

จ Duff, $12 \mathrm{~L} \&$ Phil at 376 (cited in note 30 ).

${ }^{9}$ See text accompanying notes $\mathbf{1 5 - 2 0}$. 
blame another actor more because she deliberated about a decision to become a thief, weighing her moral qualms against a need to, for example, feed her children? The majority view makes these judgments ahead of time and in the abstract, endowing the actor's speed of decision with a privileged moral status and excluding from consideration all other potentially relevant factors. ${ }^{91}$

\section{B. Rejecting the "Settled Dispositions" Minority View}

Although the minority's totality of the circumstances approach avoids the narrowness of the majority approach, it too must be rejected. Most of the courts taking the minority position have adopted an overly broad understanding of character that encompasses both an actor's settled dispositions and his motivations for the specific criminal act in question. A character-based approach to the aberrant behavior departure entails an expansive analysis that reaches beyond choice in order to fully capture moral intuitions about blame and punishment. But the minority view goes too far. These courts use the totality of the circumstances test to give moral credit to defendants who previously led exemplary lives. ${ }^{22}$

A properly constructed character-based approach ought only identify gaps between legal and moral norms; that is, when the Guidelines-mandated sentence attached to a criminal act is out of step with moral blame in a particular instance. "Settled dispositions"-prior good deeds, support of family, lack of previous misbehavior-do not have the same intrinsic connection to moral blame as do the emotions and motivations underlying the criminal act itself. These characteristics of the actor are temporally and causally separate from the act the criminal law seeks to punish. Moreover, when courts award moral credit under the rubric of aberrant behavior, they open the door for actors with bad characters to mimic the signs of good character-paying in advance, as it were, for the right to commit crimes at a reduced cost. A settled-dispositions interpretation of the aberrant behavior de-

9t The theoretical and philosophical flaws in the majority view are compounded by its mistaken legal conclusion that the current system of criminal sentencing mandates an act-based approach. This assumption is wrong in light of Congress's instruction that courts should consider a defendant's history and characteristics along with the nature and circumstances of the offense. 18 USC $\S 3553(\mathrm{a})(1)$. It also conflicts with the Commission's statement that, in contemplating a departure, "the court may consider, without limitation, any information concerning the background, character and conduct of the defendant." USSG \& 1B1.4. Finally, the Supreme Court offers a reminder in Koon that courts should focus on individual characteristics and circumstances. 518 US at 113. See also Part II.A.

${ }^{2}$ See note 2. 
parture thus may actually obscure character, thereby rewarding the calculating and the devious.

\section{Proposing a Motivational Character-Based Definition for Aberrant Behavior}

Judicial analysis of aberrant behavior must look beyond the actor's capacity for rational choice and examine the actor's underlying emotions and motivations. At the same time, a sentencing court must eschew consideration of charitable activities, prior good deeds, lack of previous misbehavior, ${ }^{93}$ history of steady employment, and history of economic support for family. Indeed, Sentencing Commission policy statements already discourage courts from using most of these factors as grounds for departure. ${ }^{94}$

A character-based approach to the aberrant behavior departure should focus instead on the motivations for the criminal act. On at least one occasion the Ninth Circuit has done just this: the court recognized that "a defendant's exemplary life prior to his criminal involvement does not, by itself, justify a departure for aberrant behavior" and examined the totality of the circumstances for the defendant's "motivations and any surrounding extenuating circumstances. ${ }^{95}$ Under the Ninth Circuit approach, the proper standard of comparison is not the defendant's own prior conduct but rather the behavior and motivations of other offenders committing the same offense. Only the latter comparison reveals the presence or absence of a gap between legal and moral norms that would justify an aberrant behavior departure. A particular defendant deserves a reduced sentence not because he is a hard-worker, a family man, and usually a law-abiding citizen; rather, he deserves a reduced sentence because the motivations behind his crime make him less morally blameworthy than most others who have committed the same offense.

For example, a defendant convicted of possessing an illegal shotgun might qualify for the departure because his motive of family protection distinguished him from the ordinary gun offender. ${ }^{96} \mathrm{~A}$ defendant who bribed an immigration official might qualify, too, if she committed her act in order to help a friend

* The Guidelines, of course, already account for criminal history on the sentencing grid itself. While this is unobjectionable, courts should not go beyond "official" criminal history to measure the nature and quality of all the defendant's previous acts, punished or unpunished.

\% USSG § 5H.

${ }^{95}$ United States $v$ Pierson, 121 F3d 560, 564 (9th Cir 1997).

${ }^{83}$ See United States $v$ Lam, 20 F3d 999, 1005 (9th Cir 1994). 
while most other defendants who commit the same offense act for personal or pecuniary gain. ${ }^{97}$ Even Russell's spontaneous and thoughtless act could bring him within the reach of the departure if the sentencing court determined that his opportunistic motive made him less morally culpable than a defendant demonstrating calculating greed. A properly constructed character-based approach to the aberrant behavior departure would allow a scope of inquiry just broad enough to generate these kind of moral judgments while avoiding the problem of "moral credit."

\section{The Problem of Inaccurate Moral Judgments}

A possible objection to the character-based approach to sentencing arises from another perceived gap between morality and legal institutions-the gap between society's definition of moral blame and moral blame as individual judges define it. ${ }^{98}$ In other words, how can we be certain that individual judges make sentencing decisions that are consonant with society's moral intuitions? Professors Dan Kahan and Martha Nussbaum illustrate this problem with the example of a Texas state court judge, Jack Hampton, who imposed a lenient sentence on a killer because his two victims were homosexual. ${ }^{99}$ According to Judge Hampton, the victims would not have been killed "if they hadn't been cruising the streets picking up teen-age boys." ${ }^{p 100}$ Judge Hampton also indicated that he took into account the fact that the defendant had no criminal record, was attending college, and was reared in a good home by a police officer father. ${ }^{101}$ Predictably, the judge's decision caused outrage in the community and among gay rights groups nationwide. ${ }^{102}$ Soon after the sentencing, Judge Hampton reported that he had received death threats and had been advised by the police to leave town. ${ }^{103}$

A character-based approach to sentencing would deny people like Judge Hampton the ability to afford a defendant moral credit for factors such as lack of a criminal record, college attendance, and family background. However, because it would permit him to give weight to a defendant's emotions and motivations-in this

${ }^{7}$ See United States $v$ Takai, 941 F2d 738, 743 (9th Cir 1991).

* See Kahan and Nussbaum, 96 Colum L Rev at 362 (cited in note 34) (describingand dismissing as unpersuasive-this objection to judges' and juries' examination of the moral quality of offenders' emotions).

See id at 364.

${ }^{100}$ Lisa Belkin, Texas Judge Eases Sentence for Killer of 2 Homosexuals, NY Times 8 (Dec 17, 1988).

${ }^{101}$ Id.

${ }^{100} \mathrm{Id}$.

${ }^{100}$ Id. 
case homophobia - a character-based approach would risk that a judge will get it wrong and apply a standard of morality inconsistent with that of society at large. There are several responses to this problem. First, the problem will not arise often because departures from Guidelines-prescribed sentencing ranges are the exception, not the rule. ${ }^{104}$ Second, the entire criminal law system is based on the fundamental assumption that legislative and judicial decisionmakers are equipped to make accurate moral assessments. ${ }^{105}$ Finally, the limited exercise of judicial discretion under the Guidelines is constrained by the existence of appellate review. District court judges must enumerate specific reasons for departure, at the risk of being reversed. ${ }^{106}$

\section{CONCLUSION}

The United States Sentencing Guidelines seek to provide uniformity in criminal punishment, ensuring that similar cases are treated similarly. Because legal norms usually represent moral norms accurately, this approach generally succeeds in fixing punishment in proportion to moral blame. Problems occur at the margins where the unusual case presents itself and the Guidelines force us to punish a defendant more severely than our moral intuitions tell us is necessary. To alleviate this problem, the Guidelines include provisions for departure from the sentencing grid, allowing limited exercises of judicial discretion to align legal and moral norms. In order to align these norms perfectly, however, it is necessary to know where the gaps are. Should courts focus on impairment of choice when assessing moral culpability? Or is it the assessment of character that drives moral intuitions?

Choice theory fails as an explanation for criminal responsibility because it is irremediably incomplete. Only character theory, which embraces instinctive considerations of unchosen emotions and motivations, provides a complete picture. If departures such as the one for aberrant behavior are to identify and fill the gaps between legal and moral judgments, the judicial inquiry must be tightly focused on the motivational components of an ac-

${ }^{104}$ See Michael S. Gelacak, Ilene N. Nagel, and Barry L. Johnson, Departures Under the Federal Sentencing Guidelines: An Empirical \& Jurisprudential Analysis, 81 Minn L Rev 299, 359 (1996) (The national average for downward departures is about 6 percent.); United States Sentencing Commission, 1995 Annual Report 85-86 (1995) (Between 1989 and 1995, the annual departure rates for all factors other than assistance to the government ranged from 5.8 to 8.4 percent.).

${ }^{205}$ See note 98.

${ }^{100} 18$ USC § 3553(c). 
tor's character. The inquiry must therefore be neither limited to choice nor expanded to include moral credit for past action. Instead, the sentencing judge must examine the most reliable expressions of character before her: the emotions and motivations underlying the criminal act itself. The resulting decision to depart will thus achieve the desired alignment between morality and legality. 


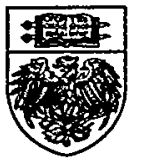

